Invited essay: Journal of International Wildlife Law and Policy

\title{
Brushes with the Law: a conservation scientist's perspective on legal solutions and impediments from Scottish Wildcats to African Lions ${ }^{1}$
}

D.W. Macdonald*

"Wildlife Conservation Research Unit, Department of Zoology, University of Oxford, The Recanati-Kaplan Centre, Tubney House, Abingdon Road, Tubney, Oxon OX13 5QL, UK

Corresponding author: D.W. Macdonald, david.macdonald@zoo.ox.ac.uk

Keywords: CITES, conservation, lions, pangolins, taxonomy

"You cannot make men good by law: and without good men you cannot have a good society." C. S. Lewis

${ }^{1}$ This invited essay is based on a keynote lecture delivered to the $18^{\text {th }}$ International Wildlife Law Conference at Tilburg in April 2018 


\begin{abstract}
I suggest here that the requirements for conservation evidence within regulation are cyclical in nature, and I describe the key stages in this cycle of conservation regulation. In particular, I focus on: (1) the type of evidence required (illustrated by the case of water voles disrupted by riverside development), (2) the clarity of evidence in terms of its implications for policy, (illustrated by the harrowing case of the endangered Scottish wildcat hybridising with the pestilential feral domestic cat), (3) the actual impact such evidence has in practice (illustrated by the legal confusions arising from the changing taxonomy of protected species), and (4) the role of evidence in assessing regulatory efficacy (which returns us to point ' 1 ' in the cycle) (illustrated by evidence of the (in)humaneness of, for example, rodent traps, various instances of wildlife trade, and the efficacy of international conventions). The paper concludes with a series of reflections on how conservation researchers might engage with legal experts and practitioners for the benefit of wildlife conservation in the $21^{\text {st }}$ Century: through transdisciplinary research, ethically informed and actively applied.
\end{abstract}




\section{Introduction}

The intersection of wildlife management and environmental law stretches back many centuries. In earlier times, regulation tended to protect species for the benefit of the human elites who wished to hunt them. In more recent decades, as the conservation movement has emerged from its roots in game management (Adams, 2004), attention has shifted to a broader collection of organisms. In diverse geographies across the planet, new and existing national and international laws and regulations have been developed to protect this wider 'biodiversity'. Lawmakers, in times both past and present, have relied on applied biological research to inform the design of effective regulation. In this paper, I reflect on my own experience, and that of the Wildlife Conservation Research Unit, in providing informed evidence and advice for the use of law-makers and decision-takers. The law has always provided a framework within which conservation imperatives and actions inescapably reside. For example, in 2001, I published a book on the future, both pragmatic and aspirational, of mammal conservation in the UK, and inevitably it contained a hefty section of the law pertaining to wildlife and how it might be reformed (pages 175-197, Macdonald and Tattersall, 2001). Of ten top priorities for immediate action for conservation, we listed as fourth the need to 'extend legal protection to include local wildlife sites, buffer zones and corridors', and of a further ten topics for deeper thought, we listed first the need to simplify the organically growing wildlife legislation, perhaps through a Consolidation Act. Now, almost two decades later, I suggest here that the requirements for conservation evidence within regulation are cyclical in nature, and describe the key stages in this cycle of conservation regulation (see Figure 1). In particular, I focus on: (1) the type of evidence required, (2) the clarity of evidence in terms of its implications for policy, (3) the actual impact such evidence has in practice, and (4) the role of evidence in assessing regulatory efficacy (which returns us to point ' 1 ' in the cycle). The paper concludes with a series of reflections on how conservation researchers might engage with legal experts and practitioners for the benefit of wildlife conservation in the $21^{\text {st }}$ Century: through transdisciplinary research, ethically informed and actively applied.

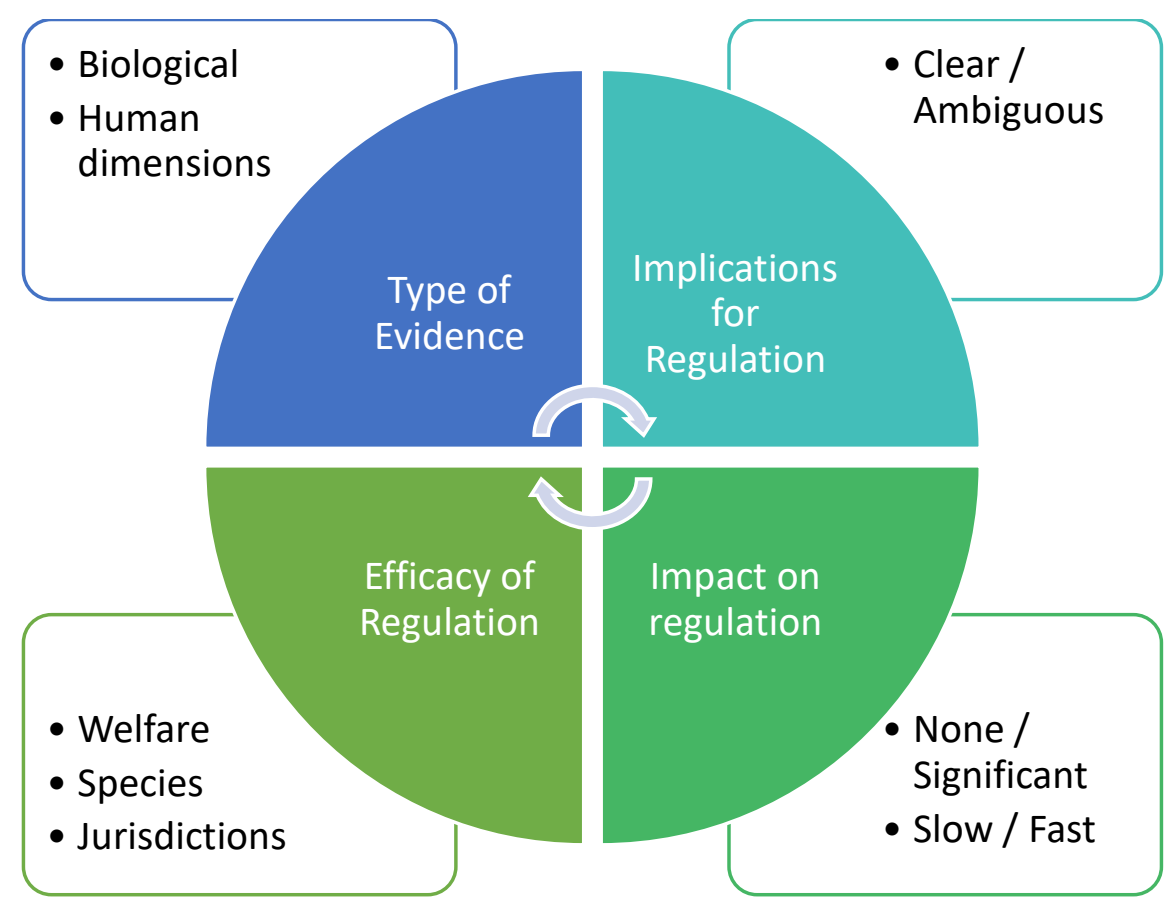


Figure 1. The evidence cycle in conservation regulation.

Against that background, thinking of the interface between the complexities of ecology and the heavy hand of intervention, I first, lightly, remind readers of Charles Elton's caution of the hazards of meddling too readily:

'In 1891 and 1892 voles multiplied on grazing areas in the Border countries of Scotland, with the result that lambs starved and Parliamentary Committee was set up to see what should be done about it. After the Committee had sat, the voles disappeared' (Charles Elton, The Ecology of Animals ( $2^{\text {nd }}$ Edn. 1946).

\section{Types of evidence}

Conservation research is by no means limited to 'conservation biology', instead encompassing a range of social, environmental, ecological and evolutionary sciences of relevance to the field. Nevertheless, a useful distinction can be made between research into 'biological' and 'human' dimensions of conservation situations (albeit recognising that the distinction is heuristic, and the categories are best understood as 'ideal types' rather than fully distinct endeavours). Biological research tends to focus on the behaviour of species and ecological changes, whereas human dimensions research concerns myriad individual behaviours and societal contexts that shape wildlife. Each of these produces different types of 'evidence', often based on different epistemologies.

A good example of how biological research into animal behaviour can inform policy comes from our work on water voles, Arvicola amphibius. During the working lifetime of biologists studying them in the UK, these mammals have gone from abundant to widely extirpated to, through a remarkable story of conservation research, promising recovery at a local, if not national level (McGuire \& Whitfield 2017). This unusual case history is documented by Moorhouse et al. (2015), the results of which have catalysed changes in UK law (Strachan et al 2011). Prior to 2008 water voles only received limited legal protection in England, Wales and Scotland, however latterly water voles in England and Wales have received full protection under UK law (extends to the animals, their burrows, places of shelter etc). Nonetheless, in January 2016 Natural England, the statutory body in England, issued a licence to allow certain development works to proceed that would disturb water vole habitat for a distance of no more than $50 \mathrm{~m}$ along riverbanks between Feb 15 - April 15 . The idea was that the $50 \mathrm{~m}$ limit would allow water voles to easily move up- or down-river. However, there was no evidence that this approach serves to protect the rodents. Our research, focussing on the actual behaviour of water voles, demonstrated that on the contrary, they are not 'displaced' (Gelling et al., 2018). Instead a significant number remain in their burrows following the disturbance, therefore facing increased risk of death/injury as the development works proceed. Worse, in the absence of the removed vegetation, the water voles may plausibly face an increased risk of predation. Water vole populations are already at their lowest in spring due to up to $70 \%$ population mortality over winter, so if the current methodological approach is continued it carries a risk of eradicating small, already vulnerable populations. Our approach, and collaboration with Natural 
England (Gelling et al., 2018), highlighted this risk and considerations that should be explored more fully.

\section{Implications of evidence}

Research in conservation biology is usually conducted with practical application in mind. However, even with well-designed studies, the evidence provided may need significant translation in order to be useful in legal and regulatory contexts. The implications of conservation research span a continuum of clarity, from those with obvious and immediate implications for regulation (like the water vole example above), to others where the required action is less obvious. In such contexts, the relationship between evidence and regulation, and between biologists and legal experts, can be complex. An example of this kind of situation from our own work concerns the plight of Scottish wildcats.

The Scottish wildcat forms the British population of the European wildcat (Felis silvestris) and is Britain's only remaining native felid, widespread across the Britain until the 18th century when hunting for fur, persecution as vermin and habitat loss confined it to Northern Scotland (Kitchener, 1995; Lovegrove, 2007). The most recent official survey (Davies and Gray, 2010) and subsequent camera trapping surveys by various different organisations (Hetherington and Campbell, 2012; Littlewood et al., 2014; Kilshaw 2015; Kilshaw et al., 2015) all indicate that the wildcat remains restricted to northern Scotland but that due to hybridization with feral domestic cats (F.s.catus), they are rapidly declining in numbers. In 2004 we published the first Wildcat Action Plan (Macdonald et al., 2004) and estimated there were about 400 wildcats left. A bit over a decade later, extrapolation from our recent camera trapping puts the population at somewhere between 115-314 individuals (Kilshaw, 2015).

The Scottish wildcat is currently protected under Annexe IV of the European Directive which has been transposed into UK domestic legislation through Schedule 2 of the Conservation (Natural Habitats \& c) regulations 1994. This protects the wildcat and its shelter, but the problem is it is extremely difficult confidently to identify a wildcat because one of the biggest threats to this species across Europe, and beyond, is hybridization with the domestic cat (Driscoll and Nowell, 2009; Stahl and Artois, 1995; Yamaguchi et al., 2015). Hybridization and, over time, introgression (i.e., the transfer of genetic information from one species to another as a result of hybridization between them and repeated backcrossing), between the Scottish wildcat and the domestic/feral tabby cat, has resulted in a wild-living cat population in Scotland with a range of morphological and genetic characteristics (Daniels, 1997; Daniels et al., 1998), which complicates both study of the species and enforcement of conservation legislation (Macdonald et al., 2004; Macdonald et al., 2010; Senn et al., submitted).

Hybridization is not recent - wildcats have been potentially interbreeding with the domestic cat since it was introduced into Britain by the Romans some 2-3000 years ago (Hamilton, 1897; Maltby, 1979; Noddle, 1987). Early naturalists realized this (Bewick, 1820; Darwin, 1875), and the negative impact of hybridization was first recognised by Cocks (1876), with later evidence that inter breeding was occurring documented by other researchers (Corbett, 1979; Gray, 1971; Pitt, 1939). However, despite being recognised as occurring, the first wildcat specimen was not curated until 1904 (Pocock, 
1951) so even the type specimen, the bench mark, against which all other samples are compared, may already contain domestic cat genes. There is a real possibility that introgression will cause the genetic extinction of the wildcat in Scotland, or may even have done so already. The main problem facing wildcat conservation has been diagnosing a wildcat, making monitoring and survey difficult. Further, ecological data are few, so conservation management conundrums are legion. Should hybrids be weeded out to allow the native population to recover? If no genetically pure wildcats remain (which might be the case in Scotland), then should hybrids be protected as repositories of wildcat genes? And if so, which hybrids?

The wildcat is a European 'protected species' but feral cats can be legally controlled, and hybrids are currently not protected. In short, a gamekeeper on the misty moor, squinting through his rifle sight, faces a perplexing dilemma as he squeezes the trigger: if that which he shoots is a feral domestic, then he will be doing his job, if it's a wildcat he faces legal consequences, and if it's a cross-breed his fate depends a bit on the magistrate's view on the rules of precedence in taxonomy, and thus whether wildcats are actually a subspecies of domestic cats or not. Indeed, in Stonehaven Sheriff Court on 24th May 1990 the law became inoperable because nobody could agree what it was protecting. No one has been taken to court in the UK on this matter since. This topic reminds me of the Bern Convention's Standing Committee Recommendation No. 173 (2014) on wolf-dog hybrids. (The Recommendation calls on Convention parties to ensure that "removal of wolf-dog hybrids takes place after government officials and/or the bodies entrusted by governments for this purpose and/or researchers have confirmed them as hybrids using genetic and/or morphological features). In this parallel example, the Recommendation is that removal should only be carried out by 'bodies entrusted by the competent authorities with such a responsibility, while ensuring that such removal does not undermine the conservation status of wolves.' It also calls on parties to adopt "the necessary measures to prevent wolves from being intentionally or mistakenly killed as wolf-dog hybrids'. There may be lessons here for wildcats (https://onlinelibrary.wiley.com/doi/pdf/10.1111/reel.12052).

So, what is a wildcat? We've spent 20 years on this question and we've found that whether you look at their guts, pelage, genetics or skulls, wild-living cats assort into two classes, those closest to domestic cats, and those furthest from domestic cats (Daniels et al., 1998; Beaumont et al., 2001; Macdonald et al., 2004; Yamaguchi et al., 2004a,b). While nobody was around to record what a preiron age pristine wildcat was like, we assume that it was most like those contemporary cats deemed 'Furthest-from-Domestic'. However, in practical terms, the aforementioned game-keeper about to shoot a cat may not have his callipers to hand, and worse, in legal terms, individuals 'furthest-fromdomestics' on one measure may not be 'furthest-from-domestics' on another. Indeed, some unlikely looking specimens are full of wild genes, and vice versa. Currently wild-living cats are given a combined score based on their mtDNA (inherited through the mother) and 35 Single Nucleotide Polymorphism's or SNP's (SNIPS) (Senn and Ogden 2015). The higher the score the genetically closer an individual is to a (furthest from domestic) wildcat. Cats with a score $>0.75$ are considered to be wildcats. However, when the genetic scores were compared to their pelage score (Daniels et al., 1998; Macdonald et al., 2004; Kitchener et al., 2005), there was only a loose correlation between what they looked like and their genetics. Importantly though, two cats that met our strictest pelage criteria were those that scored highest genetically (Fig. 2). We use 7 pelage characteristics for strict diagnosis of a wildcat (Fig. 3). Each characteristic is given a score of 1 for domestic cat traits, 3 for wildcat and 2 for hybrid or in between. Thus a wildcat scores 19 or more. However, to reduce the margin of error in the field and protect better quality hybrids that may possess valuable wildcat genetic material, we use a more relaxed criteria whereby a wildcat should score 14 or more with no 
scores of 1 (domestic cat traits) for any of the 7 pelage characteristics or a further 8 pelage characteristics (Macdonald et al., 2004; Kitchener et al., 2005). An even simpler definition of a wildcat has been provided for gamekeepers and land managers: if it looks like a wildcat and acts like a wildcat then it should be considered a wildcat.

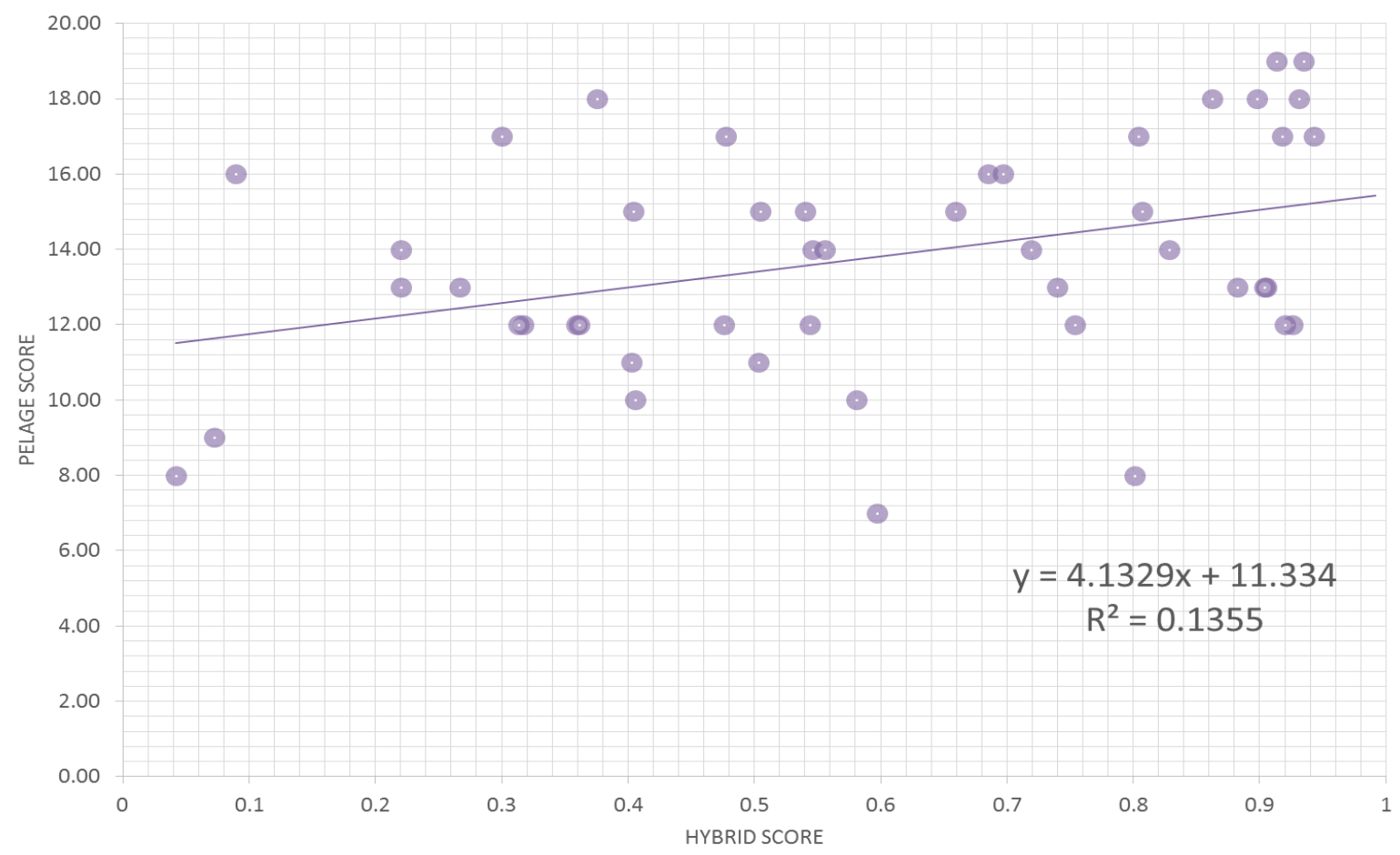

Figure 2. Genetic versus pelage score for a sample of wild-living cats.
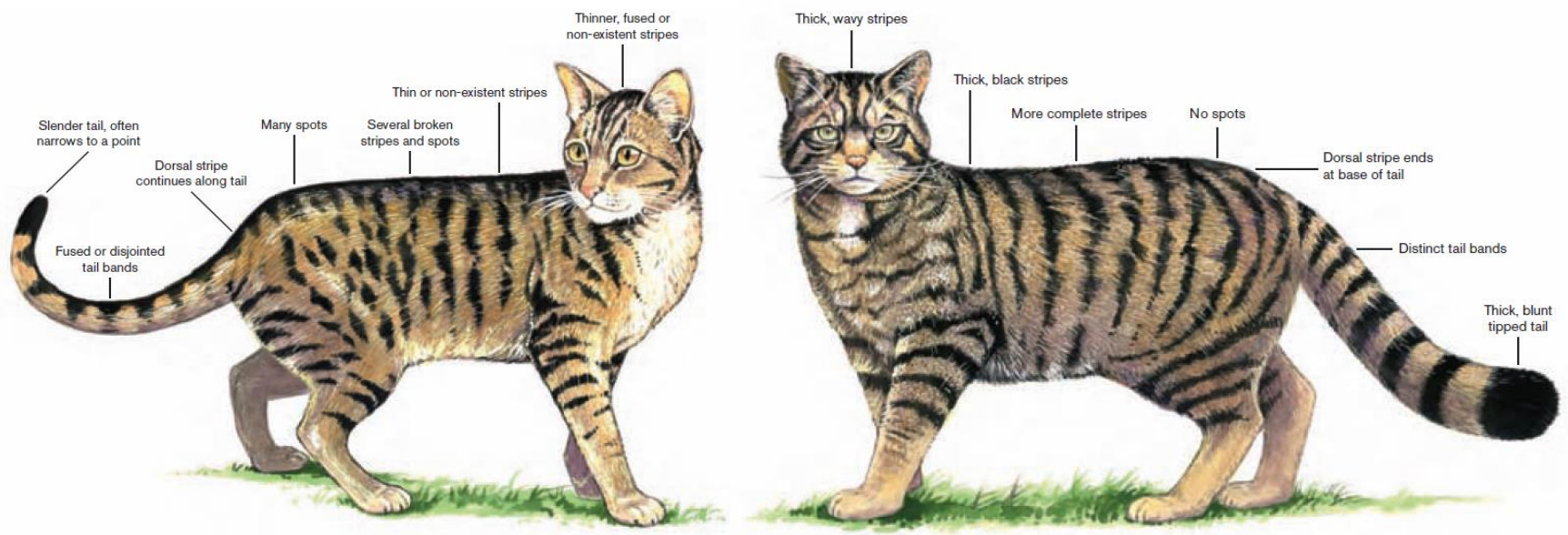

Figure 3. Pelage characteristics used to distinguish domestic cats from wildcats.

\section{Impact on Regulation}

As the case of the wildcat shows, the implications of evidence for conservation regulation may be ambiguous. However, even when the evidence points towards clear and indisputable actions, these are not always forthcoming. Legal jurisdictions and regulatory processes differ across the world; and conservation scientists have differing amounts of access and influence across various contexts. 
Regulations may be amended or changed in the face of new evidence, but the speed at which changes occur can vary from immediate to glacial. Following on from the wildcats, some illustrative examples of the ways in which evidence can lead to change, fast and slow, can be found in the context of taxonomic nomenclatures.

To prosecute wildlife crime, species must be known by a legally binding name, recognised by national laws and international conventions. Sometimes, these conventions and laws do not keep pace with developments in the biological evidence. We have identified, for example, a range of problems linked to the fact that China's List of Fauna under Special State Protection (LFSSP) has not been updated since it was implemented in 1989 (Zhou et al. 2015a; 2016a). Consequently, the taxonomic names of 18 of 232 vertebrate taxa (including 13 of 82 listed mammals) no longer match the CITES Species+ database. Furthermore, 21 vertebrate species (18 mammals) which do not appear on China's LFSSP are now considered native to China due to the discovery of new population distributions and phylogenetic relationships. These various contradictions can lead to significant gaps in regulatory protection. For example, if, as taxonomists and biogeographers propose, the Malaysian and Indian pangolin do indeed have a native range extending into China, how can one prove that these species are being trafficked internationally in violation of CITES? Yet neither are they listed as a protected species on China's 'native' LFSSP - and so strictly speaking they're about to fall into no-man's land, devoid of protection.

As another example, again relating to the speed of change, the Chinese goral is listed on the LFSSP under the name "Naemorhedus goral", which taxonomists have recently split into three species: the Himalayan goral (N. goral) in southern Tibet (still protected under the LFSSP), the long-tailed goral ( $N$. caudatus) in the northeast of China, and the Chinese goral ( $N$. griseus) throughout the rest of China. The latter two thus slip through the legal net, as they are no longer covered by the relevant regulations. Also, the LFSSP still lists just the obsolete Chinese mainland serow, as Capricornis sumatraensis, despite in 2005 this species having been split taxonomically into the Chinese serow ( $C$. milneedwardsii) and the Sumatran serow (C. sumatraensis), which is indigenous to Indonesia, Malaysia and Thailand, and thus subject to CITES. And another: the LFSSP includes all leaf monkeys in China under the generic name of "Presbytis spp.", and provides them with the highest legal protection. However, in 2005, Chinese leaf monkeys were re-assigned into two genera:

Trachypithecus and Semnopithecus. Those retaining the generic name Presbytis spp. now occur only outside China, in other Southeast Asian countries. Leaf monkeys were thereby stripped of any formal protected status in China.

\section{Efficacy of Regulation}

Conservation research usually addresses contexts where regulations already exist. In such situations, researchers can assess the conservation status of species, the various threats to their survival, and the efficacy of existing regulations in conserving the species of concern. Conservation evidence can be utilised to develop and reform laws and rules, and to address existing shortcomings. In this section, I reflect on three ways in which our research has assessed regulatory efficacy, in terms of: (i) welfare outcomes, (ii) conservation outcomes (desired, perverse, and avoided), and (iii) international cooperation. 


\subsection{Welfare outcomes}

Conservation interventions may utilise the traditional tools of wildlife management in order to control invasive or otherwise problematic populations. However, not all such tools are effectively regulated, and conservation practitioners need to assess the welfare implications of any tools they intend to use. In the UK, for instance, spring traps are widely used for killing small to medium-sized mammals, such as rabbits, squirrels, mink, stoats, rats, weasels, mice etc. In general, these traps are required to meet welfare approval standards under the Pests Act 1954. However, for historical reasons, break-back traps, for killing rats and mice, and mole traps, are exempt and therefore totally unregulated and yet legally available in the UK. We examined the potential welfare impacts of unregulated trapping in a wide range of unregulated rat, mouse and mole traps (Baker et al 2012). To avoid the welfare, practical and financial costs of conducting killing trials we measured mechanical trap performance as a proxy for welfare performance. We measured impact momentum and clamping force in 18 types of rat trap and 24 types of mouse trap (Figure 4). Both forces varied several-fold among traps for each species, and there was considerable overlap between the weakest rat traps and the strongest mouse traps; this is particularly concerning given that rats are about 20 times heavier than mice. We repeated mechanical trials with scissor, half-barrel and Talpa mole traps (Figure 5). As with break-back traps there was enormous variation in performance among each mole trap type and significant differences in performance among trap types. Next we conducted post-mortem examinations on 50 moles killed by trappers (Baker et al 2015). Most moles were struck on the thorax and/or abdomen, none on head/neck and the primary identifiable cause of death was acute haemorrhage. X-rays showed that not one mole had a damaged skull or vertebrae and the injuries were not consistent with rapid unconsciousness.

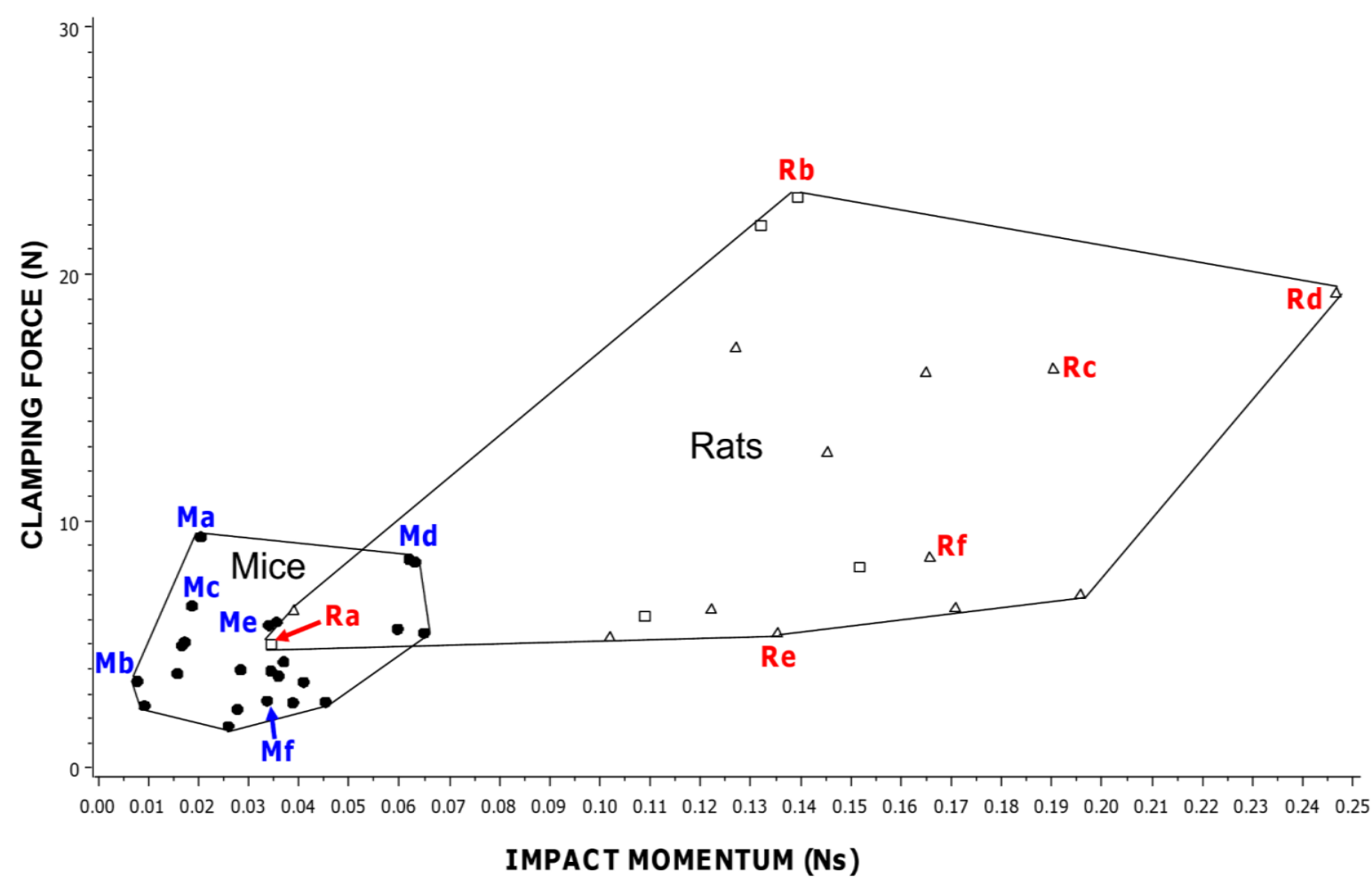


Figure 4. Clamping Force and Impact Momentum both varied several-fold among the break-back traps tested for both species. There was considerable overlap between the weakest rat traps and strongest mouse traps (Source: Baker et al 2012).

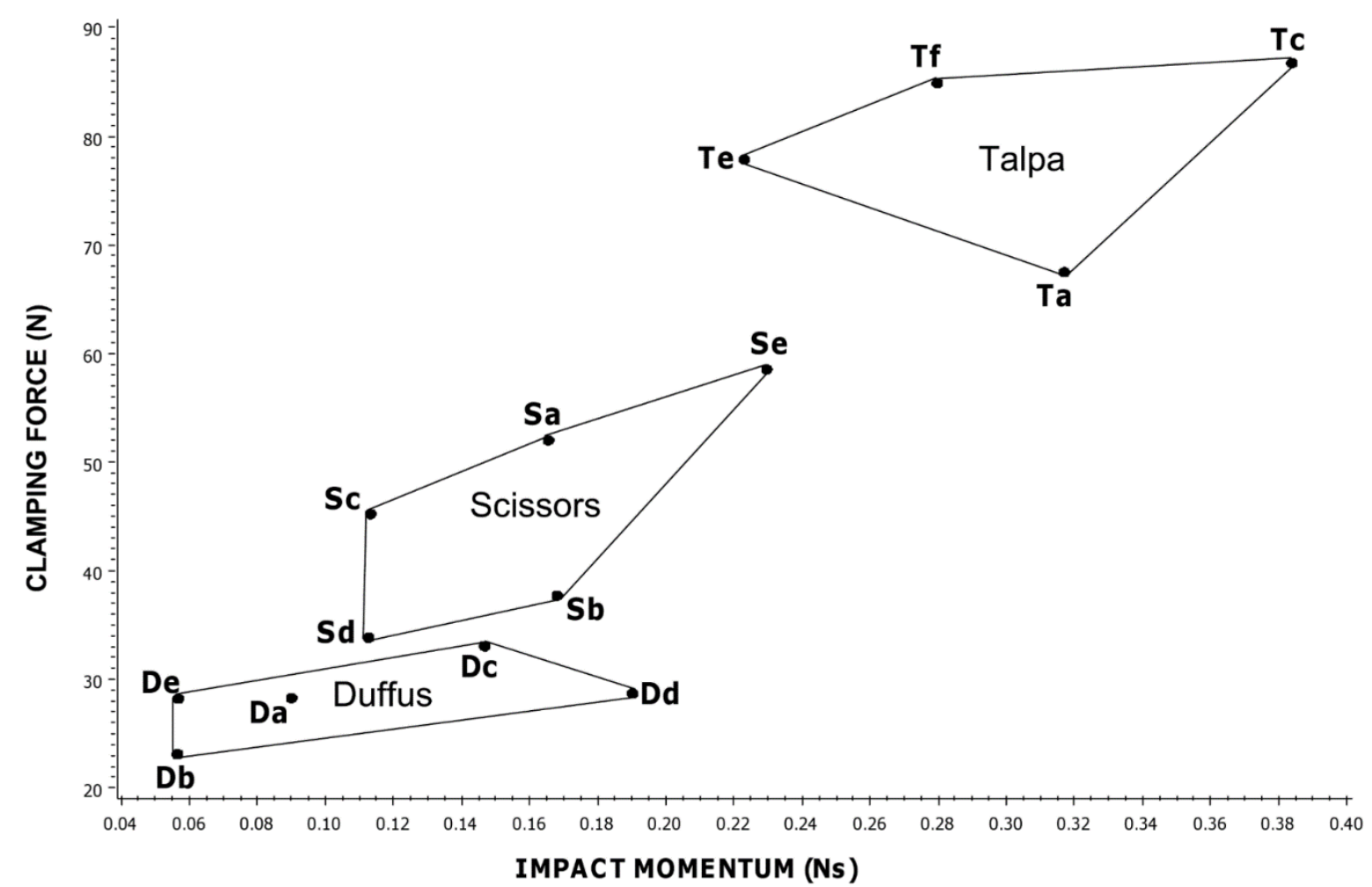

Figure 5. Clamping Force and Impact Momentum both varied several-fold across the mole traps tested. Both forces also varied significantly between trap types and among traps of the same type but of different brands (Source: Baker et al 2012).

In theory the traps tested by Baker et al (2012) could all pass, or indeed could all fail, current approval requirements. However, we think it likely that at least some unregulated traps (legal in the UK) would fail current approval tests, and that spring trap welfare would be considerably improved if the exemption was removed (Baker et al 2012). Given that rats, mice and moles probably constitute the majority of mammals killed in traps in the UK, this exemption could be of huge welfare significance.

This research thus utilises biological evidence to assess the efficacy of current regulations in welfare terms. The implications are clear but, in view of the current UK political climate, it is unlikely that the legislation will be changed soon. So, in order to actually influence practice, Baker (2016) and Baker et al (2017) proposed a Voluntary Trap Approval scheme under which manufacturers of unregulated traps could submit their traps to the licensing authority APHA (the Animal and Plant Health Agency) for testing in the same way as is done for regulated traps. The manufacturer would have to pay for tests but manufacturers of regulated traps already do this anyway. Unregulated traps that passed approval tests might receive a certification mark and other traps would be edged out of the market. Excitingly, APHA tell us that they have been approached by a trap manufacturer asking if APHA will test their unregulated traps, and APHA are in principle prepared to do so. To pass these tests, traps need to cause irreversible unconsciousness in the target species within 5 minutes in $80 \%$ or more of 
twelve tests, which is based on the AIHTS (Agreement on International Humane Trapping Standards) criteria.

Another example of assessing the welfare outcomes of wildlife and conservation regulations concerns the implications of confiscations of wild animals by regulatory authorities (Actman 2016). For instance, we reviewed the CITES trade data between 2010 and 2014 to discover the state of confiscated, live wild animals. The records revealed 64,143 individual animals, from 359 different species, reported by CITES as legal (re)exports of seized wild animals (D'Cruze \& Macdonald 2016; 2017). Doubtless this huge number is only a fraction of the true number of live wild animals that were actually seized by authorities. At the time, information about the fate of these wild animals following their seizure was not a formal CITES reporting requirement. One might wonder, sadly, which fate is worse: to become an illegal pet or be rescued in a dismal 'rescue' facility. Our work (D'Cruze \& Macdonald 2016; 2017) helped to prompt, soon after, the adoption of CITES Resolution Conf. 17.8 on disposal of illegally traded and confiscated specimens of CITES-listed species. This led in turn, again pleasingly, to the development of a questionnaire intended to review existing guidelines and evaluate current practice in the disposal of confiscated live wild animals.

But what if enforcement is undertaken successfully, and live animals are confiscated? We asked this question for 18,000 wild animals that were seized within a single year in Yunnan Province (China) alone (Zhou et al. 2016b). Euthanasia is not permitted in China. Repatriation is often impractical, or no less traumatic than the original trafficking and Chinese rescue centres are over-crowded and often perpetuate appalling welfare standards. We established that from $2010-2015$, fewer than $30 \%$ of 12,473 native reptiles (14 species) were released to the wild, while the rest went to poor, crowded sanctuaries and even into the pet / food trade. Of these, 2,000 individuals likely originated from neighboring countries. Of 155 native birds ( 20 species) all were released, however of 886 exotic birds (10 species) all were kept permanently. Of 156 native mammals (primarily primates, Asiatic bears and pangolins) almost all remained in captivity, often in appalling enclosures.

\subsection{Conservation outcomes}

Animal welfare is a pre-condition of effective conservation action, but the aim of such action is to protect endangered species in viable populations. Therefore, regulations also need to be assessed in terms of their ability to conserve species and deliver 'positive conservation outcomes'. Not all conservation regulation is successful, and an important role for conservation research is to identify how and why this is the case. Sometimes the reasons will be biological, for examples when animals behave in ways not expected or allowed for in the regulation (as in the case of the water voles in section 1). Other times, the reasons will relate to human behaviours, and where these frustrate existing attempts to regulate wildlife use. Here, I offer several examples from our own work on the human dimensions addressed by regulatory regimes.

First, elephant ivory, where both regulation and education have failed to curb consumer demand. While trade in protected species is illegal in China, private possession remains legal (Zhou et al. 2015b). For example, it is still legal to own contemporary ivory artefacts in China, whereas in the West only antique ivory (pre-1947) can be owned today, with imminent further reforms to these restrictions (Zhou et al. 2015c). To curb the ivory trade in China, one approach has been to develop 
synthetic ivory alternatives. Alas, this has been perverted in the criminals' favour, mixing real ivory with fakes (Zhou et al. 2014c). We uncovered that of 57 cases investigated in Yunnan Province, 27 involved mixed shipments, with 1,201 real products disguised among 513 fakes. Ironically, fakes are now so good that forensic tests are required to tell real from artificial, and traders demand compensation for fake products lost to destructive testing. Furthermore, consumers are also duped into paying genuine prices $(\$ 3500 / \mathrm{kg})$ for synthetic $(\$ 500 / \mathrm{kg})$ products - such is the interplay between crime and deception. Of course, according to the rule of supply and demand, an alternative to focusing on policing illegal traders would be to educate consumers and thereby reduce the market for illegal goods. Sadly, however, from our synthesis of data from across China (Zhou et al. 2015b), education is not working. Educated and affluent households consume most illegal wildlife products, whilst $84 \%$ of 600 upper middle-class respondents said in 2014 they intended to buy ivory in the future. A particular problem is the kudos and social status, rather than stigma, attached to owning exotic wildlife products. And, of course, as incomes continue to rise in China so does the number of people can afford these goods.

Second, pangolins, parrots and turtles, where illegal trade is rife in some countries despite regulations making the practice illegal. The confiscation of pangolins touches on a particularly prevalent illegal wildlife trade issue, where demand from Chinese Traditional Medicine results in pangolins (and specifically their dried scales) actually being the world's most trafficked CITES mammal species, despite the Endangered and Threatened IUCN status (E A2d+3d+4d) of the Javan (Manis javanica) and Chinese species ( $M$. pentadactyla), and both being recognised as Evolutionarily Distinct and Globally Endangered (EDGE) species. Working with legal enforcement authorities in China (Public Security Bureau for Forests (PSBF)), we uncovered the seizure of nearly $3000 \mathrm{~kg}$ of pangolin scales in Yunnan Province alone between 2010-2013 (Zhou et al. 2014a), representing almost 3000 dead pangolins, along with 259 intact pangolins, 39 of these also dead, but resulting in just 43 prosecutions. Despite penalties ranging up to life imprisonment, we discovered an instance where Beijing customs confiscated $140 \mathrm{~kg}$ of pangolin scales being sent in an airmail parcel exposing that over $1000 \mathrm{~kg}$ of scales had entered China through this route over the preceding 5 months (Zhou et al. 2014b). Pangolin scale retails for around $\$ 600$ per kg (equiv.) and so this criminal trafficking is highly lucrative, making the policing such a vast trade over China's huge borders a nearimpossible task. Turning to parrots and turtles, in China most popular pet parrot and turtle species are protected under CITES Appendix I and II and/or China's domestic List of Fauna under Special State Protection (1989) (LFSSP) and so any convicted seller or buyer could face up to 20 years fixedterm imprisonment accompanied by fines and/or the confiscation of property. With such severe sentencing, one might expect few people would take the risk. However, when we conducted five 30 day surveys of exotic pets for sale on Taobao.com (China's biggest consumer to consumer ecommerce site, akin to Ebay) we recorded 5,862 protected parrot transactions ( 46 species) and 66,927 (49 species) involving protected turtles, extrapolating to annual trade volumes of c. 14,000 and 160,000 per year, respectively (Zhou et al. subm). While we were doing this work a parrot trader was jailed for 5 years and parrot sales were banned on Taobao, but continue on other less mainstream websites. Where do these animals come from - wild caught or capture bred? The question is currently unanswered. Again, the importance of conservation research in these examples is in demonstrating where conservation regulations are not being effectively applied.

Third, monitor lizards (Varanus), where illegal trade occurs under a thin veil of disguise to escape 
regulatory attention. 'Hatha Jodi' is, apparently, a rare Himalayan plant root purported to have magical powers to ward off bad luck and change lives, bringing wealth, power and contentment, qualities making it an attractive purchase on Hindu tantric stores and websites (D'Cruze et al. 2018). We uncovered a major international fraud when we identified that dealers claiming to sell plant root labelled as "Hatha Jodi", are in fact peddling dried Monitor lizard penis (D'Cruze et al. 2018). All Monitor lizards are Schedule I animals, and any trade involving them, or their body parts, is a national offence under the Indian Wildlife Protection Act, 1972. Both the Bengal and Yellow Monitor lizard (Varanus bengalensis and $V$. flavescens) are also listed under Appendix I of CITES - the highest level of international legal protection that can be afforded, prohibiting commercial trade (CITES 2017). The penalty for killing monitors or dealing in their body parts is equivalent to doing so with tigers in India and internationally. Do customers and traders really believe they are dealing with plant roots? Or is this, perhaps, a cover to disguise trade in protected lizards through the deliberate use of a code word? These consumer attitude ambiguities aside, we documented hundreds of such advertisements carried by online retailers during a 4 weeks period in June 2017 . The retailers included Amazon, eBay and Alibaba, which presumably did not realise they were involved in illegal sales, at prices of up to USD 250 apiece, of a species protected across Asia, Europe and North America ( $D^{\prime}$ Cruze et al. 2018). Thanks to our efforts all of these vendors (apart from Amazon USA and Canada) have removed Hatha Jodi products from their webpages (Actman 2017). In this case, the evidence led to a swift impact, but unfortunately this form of illegal trade has a habit of shifting location, quickly re-emerging elsewhere under a new cover story.

Fourth, star tortoises, where loopholes in existing regulations frustrate conservation success. The Indian star tortoise (Geochelone elegans) is found in parts of India, Pakistan and Sri Lanka (D'Cruze et al. 2016). It is the single most seized species of tortoise or freshwater turtle worldwide (CITES, 2017), predominately targeted for use as exotic pets. To safeguard its wild populations, India has made it illegal to own or trade this species. However, in Thailand it is still legal to own captive bred individuals. Inevitably the Thai authorities are unable to distinguish legal captive bred from illegally poached animals (Nijman and Shepherd 2015). Back in 2004, one estimate was that 10,000 to 20,000 star tortoises were being taken illegally from the wild over the species range (Sekhar et al. 2004). When we dug deeper ( $D^{\prime}$ Cruze et al., 2015) we uncovered a much more worrying reality - in just a single rural village centre in the southern Indian state of Andhra Pradesh, in 2014 middlemen collected at least 55,000 Indian star tortoises poached from nearby smaller settlements. As a result of our study, the conservation status of this species was raised from 'Least Concern' to 'Vulnerable' on the IUCN Red List of Threatened Species (D'Cruze et al. 2016) - a good example of where, following the evidence cycle for conservation regulation, the implications of evidence did lead to impact. Based on levels of illegal trade and associated seizures, we are now pushing for a transfer of the Indian star tortoise to CITES Appendix I, the highest level of international protection possible.

The previous four examples all point to the role of conservation evidence in demonstrating the shortcomings of existing laws and regulations, or the inadequacy of their enforcement. Sometimes regulations designed for purposes other than conservation can also have deleterious effects on species of conservation concern. Here it is not the conservation regulation that is being assessed, but the wider regulatory regime that affects species survival. An example from our work pertains to the effect of non-selective hunting traps on Iberian lynx. Wild animals are trapped for meat and fur, and to protect human interests. If trapping is non-selective this can have serious impacts on 
populations of non-target species (Virgos \& Travaini 2005). In 1979, non-selective trapping devices were banned in Europe under the Bern Convention but these traps continue to be used under exception clauses as well as illegally in most European countries, and in many other parts of the world (Virgos \& Travaini 2005). For instance, the Iberian lynx, Lynx pardinus, 'Endangered' on IUCN's Red List, is being killed in parts of Spain in traditional snares set for other species, such as red foxes, Vulpes vulpes. One might wonder how this could happen, as surely only selective traps would be officially approved? Indeed, in 1999, the International Organization for Standardization (ISO) created a set of internationally-adopted methods for testing various aspects of the performance of both killing and restraining traps for mammals, including trap selectivity (ISO 1999a; 1999b). According to ISO, trap selectivity equals the number of captured target animals divided by the total number of captured animals. However, this ISO formula is only a simple capture proportion, which fails to account for the availability of individuals of different species in the environment. Sadly, this formula is being used to approve traps for use with foxes in parts of Spain and threatening the endangered lynx (Iberlince 2015).

We have proposed an alternative to the ISO selectivity formula that does account for the availability of different species (Fig. 6) (Virgos et al 2016). At the time of writing, the Spanish authorities are yet to be convinced by our proposal - which is a good example of where the implications of conservation evidence do not directly lead to immediate regulatory impact (see section 3, above). Over 1200 snares have been deployed bordering lynx territory, thus jeopardising the survival of dispersers and the colonisation of new areas. The result is that fox snares approved under ISO guidance account for the largest proportion of recorded mortality in Iberian lynx (Cabezas-Diaz et al 2009). If the ISO guidance remains unchanged, use of non-selective traps is likely to lead to similar calamities elsewhere (Virgos et al 2016). Indeed, it would appear that, ISO or not, in light of this knowledge on lynx mortality, continuing to allow the use of these snares constitutes an apparent violation of Spain's obligations under various provisions of the Habitats Directive (Articles 6(2), 12(1) and 12(4)) and the Bern Convention.

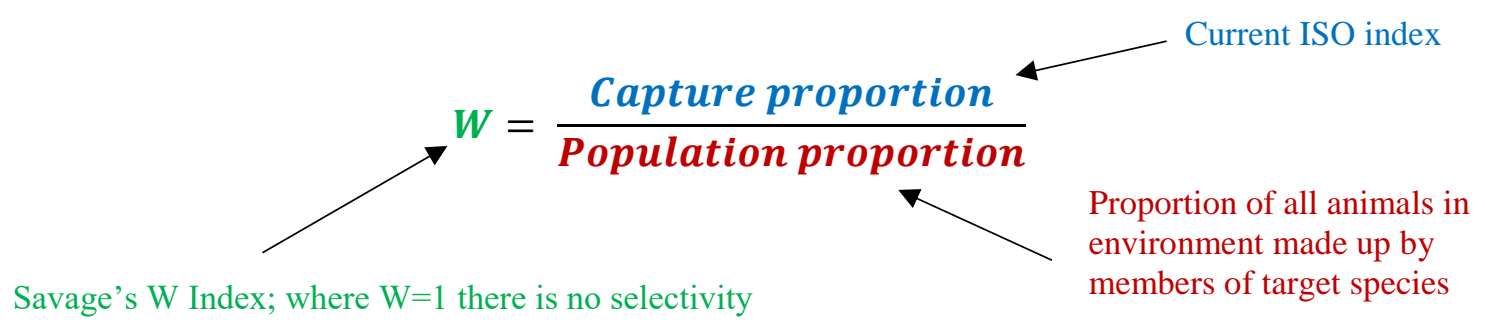

Figure 6. We proposed using Savage's Index as a measure of trap selectivity. In contrast to the existing ISO formula, Savage's Index takes into account the availability of individuals of different species in the environment.

\subsection{International cooperation}

Wildlife distributions and life histories rarely coincide neatly with human political borders. As such, a third major concern with regulatory efficacy concerns how species protections operate across multiple jurisdictions (Selier et al. (2016). Here, conservation research can shed light on the efficacy of international regulatory and legal regimes that aim to conserve endangered species. Our own 
work on lions is illustrative of the types of evidence such research can provide, as well as the paths to impact that can be utilised.

There are, sadly, perhaps less than 25,000 lions left in the wild. They persist in only $8-17 \%$ of their historic range (Bauer et al. 2018). And of the 60 remaining populations, only 6 have more than a thousand lions. The West African sub-population, in particular, is 'critically endangered' (Henschel et al. 2014). Cross-border, and thus cross-jurisdictional regulations are crucial to their survival. And the fate of lions is important beyond their own species. As apex predators, lions shape the habitats in which they live, by regulating the populations of prey species and smaller predators, with these trophic relationships cascading through the ecosystem (Ripple et al. 2014). As such ecologically important species, that require large areas in which to thrive, lion conservation thus tends to benefit a whole host of other species (Macdonald et al. 2017), serving as potent icons with the potential to generate funds for conservation (Good et al. 2017).

Lion conservation has been a focus of diverse disciplines. Conservation biologists have documented its disastrous trajectory (Bauer et al. 2018), notwithstanding the species' popularity in the developed world (Macdonald et al. 2015) and related potential to serve as an ambassador species (Macdonald et al. 2017). At the interface of development lie studies of conflict with local agriculturalists and their sociology (Loveridge et al. 2010; Western et al. submitted), and nudging towards geopolitics Dickman et al (2015) explore national differences in capacity to deliver conservation within frameworks of investment in megafauna described by Lindsey et al (2017). All these perspectives butt up against the law, whether in terms of trade - emerging, legal or illegal (e.g. Williams et al. 2017), consumption such as trophy hunting (Macdonald et al 2017) and including questions of what is legal and what ought to be legal (Vucetich et al. submitted) and the politics behind the regulatory framework that seeks to guide conservation (Bauer et al. 2018).

\begin{tabular}{c|c|c}
\hline & African Lion & Asiatic lion \\
\hline Ramsar Convention & Habitat in 39 listed sites & No listed habitat \\
\hline World Heritage Convention & Habitat in 18 listed sites & No listed habitat \\
\hline CITES & Listed in Appendix II & Listed in Appendix I \\
\hline CMS & Listed in Appendix II & Listed in Appendix II \\
\hline CBD & General relevance & General relevance \\
\hline African Convention & Listed in Annex, Class B & $\mathrm{n} / \mathrm{a}$ \\
\hline Bern Convention & Not listed, but covered & $\mathrm{n} / \mathrm{a}$ \\
\hline SADC Protocol & General relevance & $\mathrm{n} / \mathrm{a}$ \\
\hline Lusaka Agreement & General relevance & $\mathrm{n} / \mathrm{a}$ \\
\hline TFCA treaties & General relevance & $\mathrm{n} / \mathrm{a}$ \\
\hline
\end{tabular}

Figure 7. Treaties of relevance to lion conservation.

International environmental law can be used to address many of the threats faced by lions. In Troubhorst et al., (2018), together with international legal experts we assessed the protection provided by treaties including the Convention on Biological Diversity (CBD, 1992), CITES, the 
Convention on Migratory Species (CMS), Ramsar, and the World Heritage Convention (WHC). The table (Fig. 7) shows the general relevance of each of the 5 main global treaties to lion conservation, as well as for a series of additional regional treaties. In some cases, these treaties provide protection for lion habitats, and in others lions are listed on their appendices which brings with it specific forms of protection and coordination. These protections range from supporting the creation and maintenance of protected areas and species action plans, to requiring the creation of national-level protective legislation and data gathering activities. These global treaties combine to create an international legal architecture supporting conservation activities. In Hodgetts et al. (2018) we mapped each of the major threats faced by lions against the protections granted through the 'big 5' treaties, and used this analysis to explore two ways of further developing international environmental law for lions: expanding the membership of the conventions (i.e. more countries participating), and granting additional protections to species under existing conventions (e.g. through listing or 'uplisting' processes). At times, the legal protections can seem vague - such as the CBD's general requirement to prevent species extinctions ("as far as possible and as appropriate, ... [p]romote the protection of ecosystems, natural habitats and the maintenance of viable populations of species in natural surroundings" (Article 8(d)). Nevertheless, when combined, the various protections provided through international law can make a meaningful contribution to on-the-ground lion conservation. This is especially so when the provisions of these treaties (e.g. species protection and protected area creation) or the bureaucracies of the treaties (staff, funding, and other forms of support) are combined and actively utilised together.

As an example of treaties working together, Hodgetts et al (2018) trace how the listing of lions under the Convention on Migratory Species has furthered cooperative schemes involving officials from this Convention alongside partners at CITES. The Convention on Migratory Species has a wide definition of 'migratory', which it defines as species where 'a significant proportion' of their members 'cyclically and predictably cross one or more national boundaries'. It has been applied to species that simply have trans-boundary ranges in addition to those that are strictly migratory in the biological sense. Lions were recognised as 'migratory' for the purposes of the treaty in 2014 at COP11. At the 2017 COP12 in Manila, lions were then added to Appendix II of the treaty. Appendix II contains migratory species with an unfavourable conservation status that require international cooperation for their conservation and management. This was a controversial listing, and required the first vote in CMS history - previously, votes on listing proposals have not been required due to consensus. The main benefit of this CMS listing in Appendix II is the platform it provides for coordination and targetting specific threats, as demonstrated in the newly announced CMS-CITES African Carnivores Initiative. The aims of this joint initiative are to develop "concrete, coordinated and synergistic conservation programmes", "policy guidance and recommendations" and to "organize the collaboration with other conservation initiatives and organizations".

Nevertheless, as with national environmental laws, international environmental laws face some significant challenges in application, of which competing political interests, differential enforcement, and inadequate funding are particularly noteworthy (Chapron et al (2017). Conservation research can, therefore, provide evidence of where regulation can support endangered species (as above) but it is also important to assess the factors that are frustrating greater conservation success. To begin with politics, there have been some positive recent developments in the CITES treaty with respect to lions, but these need to be understood in the context of the political processes involved in CITES negotiations (Bauer et al. 2018). In CITES, Appendix I species are threatened with extinction and are subject to a ban on commercial trade, although trophies can be allowed as 'personal 
effects'. Appendix II species are those not yet threatened with extinction but that may become so if trade is not regulated - lions are currently listed on Appendix II. Proposals to uplist lions to Appendix I were made in 2004 and again in 2016, but both failed. They were controversial because of opposition from countries where lion populations are well managed, not in decline, and where trophy hunting is part of the conservation and economic regime (for an assessment of lion trophy hunting, see Macdonald 2016). The fear from such countries was that Appendix I listing would threaten the trophy hunting industry, despite the 'personal effects' allowance. While the proposal was not successful, it did lead to a new 'annotation' to the Appendix II listing, which set a zero annual export quota for lion bones from wild lions, traded commercially. But it allowed trade in bones from captive South African lions so long as an annual quota was set and enforced. The annotation, combined with a series of targeted initiatives including the African Carnivores Initiative (mentioned above), was a consensus compromise, that resulted from all sorts of political calculations and unofficial NGO inputs, allowing the parties to avoid the kind of highly politicised and fractious situation like that pertaining to ivory at CITES. Nevertheless, it is noteworthy that in this case CITES is being used to address this emerging threat of lion bones, despite all the politics (Williams et al. 2017a).

Additional challenges in applying international environmental law relate to enforcement and funding. Compliance with treaties at a national and sub-national level differs. In turn this depends on governance capacity - which also differs by country. Likewise, for enforcement, where perhaps the best example is bushmeat poaching (Williams et al. 2017b). Making rules is one thing but stopping poaching quite another. Enforcement requires funding, as do many conservation management challenges. Lindsey et al. (2017) suggest that many African protected areas lack the funding to adequately protect wildlife. Figure 8 shows a 'geopolitical fragility score' for each of the remaining lion range states, following Dickman et al. (submitted), which combines a variety of governance and other socio-political metrics to map the efficacy of the state infrastructure necessary to implement effective conservation. Furthermore, treaties are limited by the fact that not all countries are parties. And finally, in some cases, there is outright resistance to (international) environmental law. This may take the form of political struggle, as in the debates over CMS and CITES listings. But it can also lead to illegal actions that defy treaty decisions and resolutions. A final challenge sometimes levelled at international treaties is their 'lack of teeth', i.e. the absence of procedures to hold countries to effectively hold nations to account when they fail to deliver on their treaty commissions. After all, species extinctions are continuing across the world, despite the widespread membership of the CBD. Public censure, the main mechanism for encouraging compliance across most of the treaties, is not always adequate to the task. In many ways, the moral obligations created or expressed through treaties are, perhaps, more meaningful than the legal ones.

In all these cases (politics, enforcement, funding, capacity, scope), conservation researchers can contribute to analyses regarding the efficacy of existing regulations by producing evidence on their outcomes (biological and beyond), and the effects of human and ecological factors in reaching those outcomes. Doing so requires research that goes far beyond biology, as I will discuss below. 


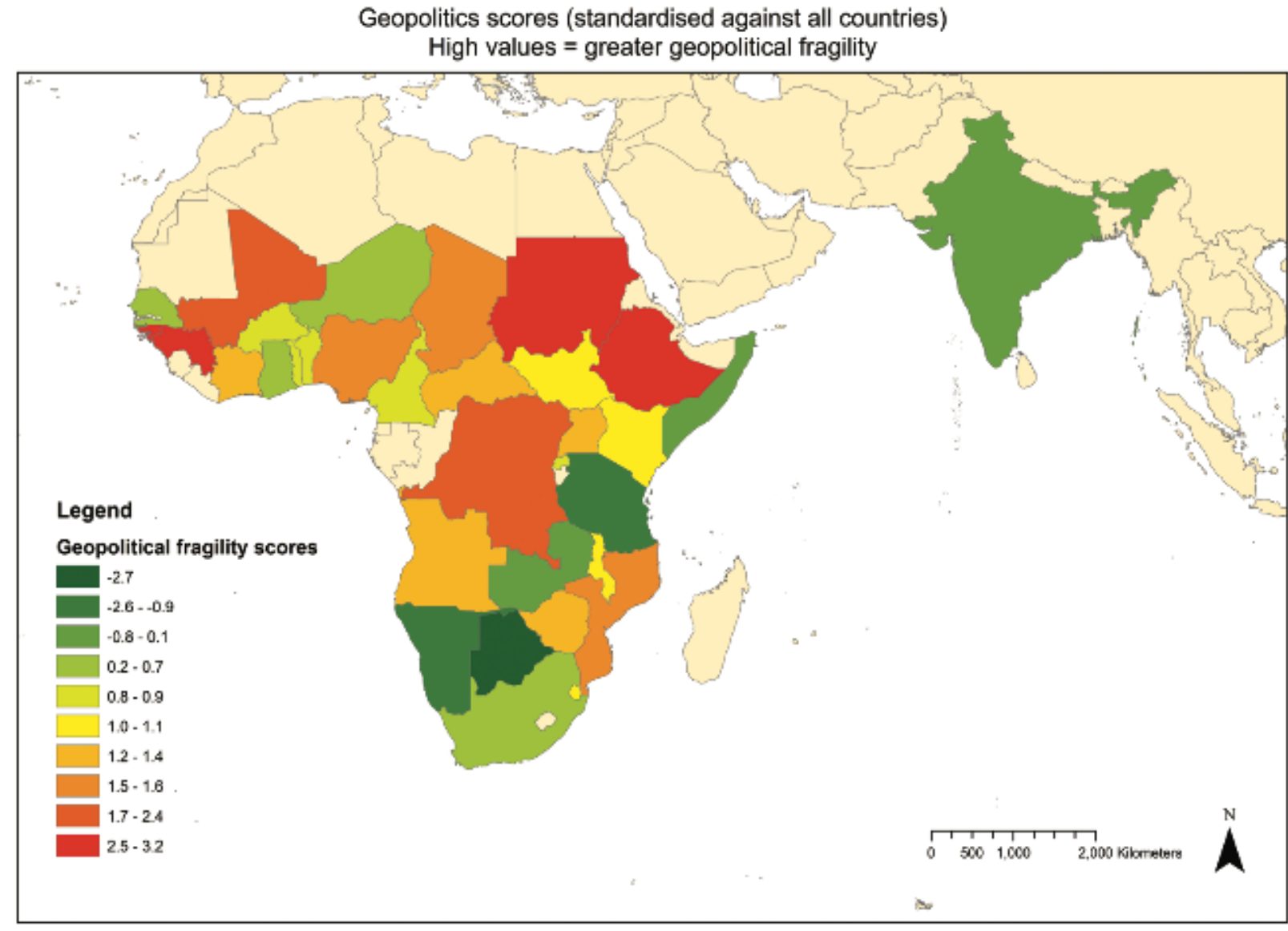

Figure 8. Geopolitical fragility score for each of the remaining lion range states.

\section{Conservation and regulation: recommendations}

In this final section of the paper, I reflect more widely on the intersection of conservation biology and legal research and practice. In particular, based on my personal experience and that of the WildCRU, I offer three recommendations for conservation researchers when engaging with the evidence cycle for conservation regulation. These are:

(i) Transdisciplinarity: Producing evidence from multiple disciplines.

(ii) Ethics: Explicitly acknowledging values

(iii) Application: Assessing the practical efficacy of regulations

First, fundamental biological research remains crucial to effective conservation regulations. After all, water voles, as we have learned, are not displaced 50 metres upriver as the designers of a new set of regulations had hoped. And feral cats hybridize with wildcats. But biological research is not sufficient on its own. People trade pangolin scales. People set fox traps that snare Iberian lynx. People desire ivory statues, monitor lizard body parts, and lion bones. Of course, collaboration between biologists and the legal profession has a long history, long before the re-badging of natural history as 'conservation biology'. Nevertheless, the forms of evidence required for effective conservation regulation need to reach beyond biology and the law. Requiring, rather than mere requesting, this 
out-breeding between disciplines has proven fruitful (e.g. Macdonald \& Chapron 2017). Recently, I characterised conservation's future as a holism that I call transdisciplinarity (Hadorn et al. 2006), acknowledging the unity of all knowledge beyond disciplines, implying a merging with, rather than a mere borrowing from, diverse disciplines (Macdonald in press). Transdisciplinary Conservation aspires 'to integrate with organismic and environmental sciences the assemblage of higher level (i.e. beyond biology) insights offered to conservation by economics, political science, law, sociology, international relations, development, ethics and disciplines with less quantitative epistemologies such as anthropology, environmental history, human geography and the like. These disciplines together inform choices, and effect behaviour change, at scales from individuals to empires' (Macdonald in press). In this context, Troubhorst et al call for international wildlife law to be characterized by better cooperation between wildlife lawyers and other conservation professionals ((https://academic.oup.com/bioscience/article/67/9/784/4077046)

Second, translating conservation evidence into legal regulations always involves the enactment of particular values. Indeed, the initial framing of species endangerment as a 'problem' is itself indicative of a particular value position, whether it is expressed in terms of nonhuman species' own interests, or in more anthropocentric terms through a recognition of the 'services' provided by ecosystems. Nevertheless, it is important to hold onto this explicit value position, because in the wider realm of law and regulation, conservation has to live alongside other priorities and ways of understanding. A good example of this issue of wider context is our own work on pheasants, and how conservation regulations to protect native species conflict with wildlife regulations intended to manage 'game' species (Feber et al. submitted). Indeed, where animals are hunted for sport they may be treated very differently in law. The Common Pheasant Phasianus colchicus is a non-native gamebird in the UK (which was probably brought to the UK by the Normans in the twelfth century (Rackham 1997) for which there is a high demand for sport shooting - so high that wild pheasant populations cannot be sustained at sufficient levels. To meet the demand, most shooting estates are dependent on the release of captive bred birds for the shooting season (PACEC 2006). Pheasants are reared before release in cages and then in woodland pens (Sage et al. 2005). The annual number released has increased from approximately 8 million in 1966 to around 35 million in 2005 (PACEC 2006, Larkman et al 2015). Despite being a non-native species, common pheasant is not listed on Schedule 9 of the Wildlife and Countryside Act of 1981, and controls on its release therefore do not apply. As Bicknell et al. (2010) point out, this is perverse, the justification is not ecological but economic; it serves only to allow them to be released and shot. Before their release, captive reared pheasants are classed as livestock, in a similar way to poultry, although no specific legislation regulates the breeding and rearing of birds for sporting purposes (guidance is given in relation to Section 9 of the Animal Welfare Act 2006: Defra 2009). As soon as the birds are released, they become wild. While the protection of wild birds in the UK is covered by the Wildlife and Countryside Act 1981, game birds are (for most purposes) not covered by this Act, being covered instead by the Game Act 1831, which allows them to be shot outside the close season (when they cannot be taken). Furthermore, if, at the end of the shooting season a shoot manager wishes to capture with nets any survivors for breeding, this is permitted for game birds, in contrast to other wild birds which cannot be caught in this way for this purpose (Natural England 2012). The eggs of game birds also have limited legal protection compared to other wild birds, and their nests have no protection. The contrast with other species classified as non-native is considerable. Note, then, the intersection of different policy priorities, as these different regulatory regimes come into friction. 
The reliance on captive-bred, released pheasants to support driven shoots has some parallels with what is known as 'canned' hunting of captive reared lions in South Africa, where captive lions are bred for the purpose of supplying the demand for lion trophies (an estimated 8000 lions being maintained and bred in South Africa in 2016: African Lion Working Group). In 'canned' hunts, captive bred lions are released into enclosures, of various sizes, where they are easily shot; this is considered ethically inferior even by trophy hunting supporters as there is no element of a 'fair chase' (Macdonald 2017). As with captive pheasants, their status is not straightforward. The industry is regulated by the Department of Environmental Affairs (DEA) and the Department of Agriculture, Forestry and Fisheries (DAFF) but, according to a report by the Born Free Foundation (2018), the DEA believes it does not have a mandate to look after the welfare of wild animals in captivity, stating this duty falls instead to DAFF which administers the Animal Protection Act and the Performing Animals Act. However, these Acts were never intended to deal with the welfare of wild animals held in captivity (Born Free Foundation 2018).

In both these cases, I would suggest, it is important for conservation researchers to recognise the multiple and overlapping forms of regulatory regime that govern wild animals across many jurisdictions, and to recognise the implicit ethical position implied when promoting conservation as a priority within particular contexts. For example, in a short essay on carnivore conservation Vucetich and Macdonald (2017) argued that the intrinsic value of carnivores should be taken into account when seeking to resolve human-wildlife conflict. Recognising that tensions can arise between conservation and social justice, Vucetich et al (2018) noted the general absence of guiding principles in conservation (as distinct from medicine and law) and proposed the following: Vucetich et al. (2018) argue that both the humans and the wildlife deserve fair treatment, proposing this candidate principle: 'Humans should not infringe on the well-being of others (including other humans, large carnivores, or other parts of nature with intrinsic value) any more than is necessary for a healthy, meaningful life. When the ability to live a healthy, meaningful life genuinely seems to infringe on the wellbeing of some intrinsically valuable element of nature (such as large carnivores), then the just solution will less often be found in depriving large carnivores and more often be found in rectifying an unjust inequality among humans'. This principle also focuses attention on a few ultimate causes of species loss and conflict: gross inequalities in wealth distribution within and among nations; gross inequalities in the costs associated with conservation; the crippling and pervasive influence of plutocracy; and the impact of human population growth. Considerations of this sort permeate judgments in wildlife conservation (Vucetich et al 2015). Striving to put our proposed principles for social justice (Vucetich et al. 2018) into legal context, I note that while many legal issues address person to person, or person to group, conflicts, others clearly weigh the interest of people compared to property rights or to other non-human factors. Consider the right to have space in which to live, the right to light and air, the right to forbid trespassing on property, which all value non-human interest (or the interest of humans in non-human interest). So the principle that humans should be limited in their ability to infringe on the well-being of other humans is a sound legal doctrine, as is the concept that humans should be limited in their ability to infringe on the well-being of other nonhumans, such as other animals or nature itself. Part of the legal justification for the latter is that the existence of these things forms part of what is of value to other humans, and therefore must come into the balancing, but we go further and advocate a non-anthropocentric perspective. 
Finally, I want to emphasize the importance of applying conservation research to real-world problems. At the WildCRU, the application of knowledge is part of our core purpose, enshrined in our mission statement. But, as I have suggested in this paper, the route from evidence to impact is neither automatic nor guaranteed. There are hurdles at each stage of the evidence cycle. When producing evidence, the challenges of transdisciplinarity loom. When assessing the implications of evidence, complex findings can lead to ambiguity and the dangers of impasse. When seeking impact, political challenges, and the ability to influence key actors become crucial. And when assessing outcomes, more evidence is required.

\section{Acknowledgements}

I thank Sandra Baker, Neil D'Cruze, Ruth Feber, Tim Hodgetts, Chris Newman, Christopher O'Kane and Merryl Gelling for their invaluable help with this paper, and Christopher O'Kane for his extensive support in preparing it. I am indebted to Tim Hodgetts for the inspiration of the conservation regulatory cycle, and much else besides. Arie Troubhorst first lured me into giving keynote talk that led to this article, and I am grateful for that and for his generous comments on the manuscript. I am also grateful to my two truly lawyerish friends, Don Howarth and Suzelle Smith for their kindly tutelage. 


\section{References}

Actman, J. 2016. What happens to smuggled animals after they're seized?

https://news.nationalgeographic.com/2016/09/wildlife-watch-animals-seized-smugglers/

Actman, J. 2017. How lizard genitalia became a black market craze. National Geographic magazine. Available at: https://news.nationalgeographic.com/2017/07/wildlife-watch-india-monitor-lizardpoaching-plant-root-hatha-jodi/ [Accessed January 24, 2018].

Baker, S., 2016. A Voluntary Trap Approval scheme to end trap welfare inequality in the UK. Animal Welfare, 26, pp.131-133.

Baker, S., Macdonald, D.W. and Ellwood, S.A., 2017. Double standards in spring trap welfare: ending inequality for rats (Rodentia: Muridae), mice (Rodentia: Muridae) and moles (Insectivora: Talpidae) in the United Kingdom. In: M.P. Davies, C. Pfeiffer, \& W.H. Robinson (ed.) Proceedings of the Ninth International Conference on Urban Pests. $9^{\text {th }}$. Birmingham. 9-12 July 2017. Pureprint Group, Sussex, UK, 139-145.

Baker, S.E., Ellwood, S.A., Tagarielli, V.L. and Macdonald, D.W., 2012. Mechanical performance of rat, mouse and mole spring traps, and possible implications for welfare performance. PloS one, 7(6), p.e39334.

Baker, S.E., Shaw, R.F., Atkinson, R.P.D., West, P. and Macdonald, D.W., 2015. Potential welfare impacts of kill-trapping European moles (Talpa europaea) using scissor traps and Duffus traps: a post mortem examination study. Animal Welfare, 24(1), pp.1-14.

Bauer, H. et al (2016) Panthera leo. The IUCN Red List of Threatened Species 2016: e.T15951A107265605.

Bauer, H., Nowell, K., Sillero-Zubiri, C. and Macdonald, D.W., 2018. Lions in the modern arena of CITES. Conservation Letters.

Beaumont M, Barratt EM, Gottelli D, Kitchener AC, Daniels MJ, Pritchard JK, Bruford MW, 2001.Genetic diversity and introgression in the Scottish wildcat. Molecular Ecology 10:319-336.

Bewick T, 1820. A general history of British quadrupeds: John Van Voorst, London.

Bicknell, J., J. Smart, D. Hoccom, A. Amar, A. Evans, P. Walton and J. Knott (2010). Impacts of nonnative gamebird release in the UK: a review, RSPB.

Born Free Foundation (2018). Cash before conservation: an overview of the breeding of lions for hunting and bone trade. Born Free Foundation. www.bornfree.org.uk. 
Cabezas-Dıaz, S., Lozano, J. and Virgos, E., 2009. The declines of the wild rabbit (Oryctolagus cuniculus) and the Iberian lynx (Lynx pardinus) in Spain: redirecting conservation efforts. In: Aronoff J.B. (ed) Handbook of nature conservation: global, environmental and economic issues. Nova Science Publishers Inc., Hauppauge, pp 283-310.

Chapron et al 2017. Bolster legal boundaries to stay within planetary boundaries: https://www.nature.com/articles/s41559-017-0086

Cocks AH, 1876. Wild cats: period of gestation. The Zoologist:5038-5039.

CITES 2017. Convention on international trade in endangered species of wild fauna and flora. Tortoises and freshwater turtles (Testudines spp.) Seventeenth meeting of the Conference of the Parties, Johannesburg (South Africa), 24 September - 5 October 2016. Cop17, Doc 73, pp. 83.

Daniels M.J., 1997. The biology and conservation of the wildcat in Scotland. [PhD]: University of Oxford, p. 207.

Daniels, M.J., Balharry, D., Hirst, D., Kitchener, A.C. and Aspinall, R.J., 1998. Morphological and pelage characteristics of wild living cats in Scotland: implications for defining the 'wildcat'. Journal of Zoology, 244(2), pp.231-247.

Darwin C, 1875. Variation of animals and plants under domestication (2nd Edition): New York: D. Appleton \& Co.

Davies A.R., Gray D, 2010. The distribution of Scottish wildcats (Felis silvestris) in Scotland (20062008). Natural Heritage Commissioned Report No. 360. p. 60.

D'Cruze, N. and Macdonald, D.W., 2016. A review of global trends in CITES live wildlife confiscations. Nature Conservation, 15, p.47.

D'Cruze, N. and Macdonald, D.W., 2017. An update on CITES live confiscations, in response to Lopes et al.(2017). Nature Conservation, 21, p.163.

D'Cruze, N., Choudhury, B.C. and Mookerjee, A., 2016. Geochelone elegans. The IUCN Red List of Threatened Species 2016:. http//dox.doi.org/10.2305/ IUCH.UK.2016-1.RLTS.T39430A2926441.en

D'Cruze, N., Singh, B., Mookerjee, A., Macdonald, D., Hunter, K., Brassey, C., Jennifer, R., Megson, S., Megson, D.P., Fox, G. and Louies, J., 2018. What's in a name? Wildlife traders evade authorities using code words. Oryx, 52(1), pp.13-15.

D'Cruze, N., Singh, B., Morrison, T., Schmidt-Burbach, J., Macdonald, D.W. and Mookerjee, A., 2015. A star attraction: The illegal trade in Indian Star Tortoises. Nature Conservation, 13, p.1.

Defra (2009). Code of practice for the welfare of gamebirds reared for sporting purposes. Defra, London. www.defra.gov.uk. 
Dickman, A.J., Hinks, A.E., Macdonald, E.A., Burnham, D. and Macdonald, D.W., 2015. Priorities for global felid conservation. Conservation biology, 29(3), pp.854-864.

Dickman, A. J., et al. (in prep). Determining the ecological and socio-political fragility of remaining African lion populations.

Driscoll C, Nowell K, 2009. Felis silvestris. IUCN 2010. IUCN Red List of Threatened Species Version2010.4

Gelling M, Harrington A, Dean M, Haddy EC, Marshall CE and Macdonald DW 2018. The effect of using 'displacement' to encourage the movement of water voles Arvicola amphibius in lowland England. Conservation Evidence 15, 20-25.

Good, C., Burnham, D. and Macdonald, D.W., 2017. A Cultural Conscience for Conservation. Animals, 7(7), p.52.

Hamilton E, 1897. The wildcat of Scotland. The Annals of Scottish Natural History 6:65-78.

Henschel, P., Coad, L., Burton, C., Chataigner, B., Dunn, A., MacDonald, D., Saidu, Y. and Hunter, L.T., 2014. The lion in West Africa is critically endangered. PLoS One, 9(1), p.e83500

Hetherington D., and Campbell, R (2012) The Cairngorms Wildcat Project Final Report. Report to Cairngorms National Park Authority, Scottish Natural Heritage, Royal Zoological Society of Scotland, Scottish Gamekeepers Association and Forestry Commission Scotland

Hodgetts, T., Lewis, M., Bauer, H., Burnham, D., Dickman, A., Macdonald, E., Macdonald, D., Trouwborst, A. (submitted) Improving the role of global conservation treaties in addressing contemporary threats to lions, submitted to Biodiversity and Conservation.

Iberlince (2015) El proyecto Life ? IBERLINCE activa exitosamente el protocolo para devolver a Llera a SierraMorena.

http://www.iberlince.eu/index.php/esp/component/news/newsarticle/370\#.VgV6K8saRde. Accessed 30 Oct 2015.

International Organization for Standardization (ISO) (1999a) TC191. Animal (mammal) traps. Part 4: methods for testing killing trap systems used on land or underwater. International Standard ISO/DIS 10990-4. International Organization for Standardization, Geneva.

International Organization for Standardization (ISO) (1999b) TC191. Animal (mammal) traps. Part 5: methods for testing restraining traps. International Standard ISO/DIS 10990-5. International Organization for Standardization, Geneva. 
Jenkins D, 1962. The present status of the wild cat (Felis silvestris) in Scotland. Scottish Naturalist 70:126-138.

Kilshaw K, Johnson PJ, Kitchener AC, MacDonald DW, 2015. Detecting the elusive Scottish wildcat Felis silvestris silvestris using camera trapping. Oryx 49:207-215. doi:

doi:10.1017/S0030605313001154.

Kilshaw, K. (2015). Introgression and the current status of the Scottish wildcat. DPhil, University of Oxford, pp 232

Kitchener AC, 1995. The Wildcat: The Mammal Society.

Kitchener AC, Easterbee N, 1992. The taxonomic status of black wild felids in Scotland. Journal of Zoology 277:342-346.

Kitchener AC, Yamaguchi N, Ward JM, Macdonald DW, 2005. A diagnosis for the Scottish wildcat (Felis silvestris): A tool for conservation action for a critically-endangered felid. Animal Conservation 8:223-237.

Langley PJW, Yalden DW, 1977. The decline of the rarer carnivores in Great Britain during the nineteenth century. Mammal Review 18:741-760.

Larkman, A., I. Newton, R. Feber and D. W. Macdonald (2015). Small farmland bird declines, gamebird releases, and changes in seed sources. Wildlife Conservation on Farmland Volume 2: Conflict in the countryside. D. W. Macdonald and R. E. Feber. Oxford, Oxford University.

Lindsey, P. A., et al. (2017). "The performance of African protected areas for lions and their prey." Biological Conservation 209: 137-149.

Lindsey, P.A., Chapron, G., Petracca, L.S., Burnham, D., Hayward, M.W., Henschel, P., Hinks, A.E., Garnett, S.T., Macdonald, D.W., Macdonald, E.A., Ripple, W.J., Zander, K., and Dickman, A. 2017. Relative efforts of countries to conserve world's megafauna. Global Ecology and Conservation, 10, pp.243-252.

Littlewood, N A, Campbell, R D, Dinnie, L, Gilbert, L, Hooper, R, lason, G, Irvine , J, Kilshaw, Kerry, Kitchener, Andrew C, Lackova, P, Newey, S, Ogen, R and Ross, Alan (2014) Survey and scoping of wildcat priority areas. Scottish Natural Heritage Commissioned Report (768). Scottish Natural Heritage, Inverness. ISBN 9781783911660.

Lovegrove R, 2007. Silent Fields; The Long Decline of a Nation's Wildlife. Oxford University Press.

Loveridge, A., Wang, S.W., Frank, L. and Seidensticker, J., 2010. People and wild felids: conservation of cats and management of conflicts. 
Macdonald, D.W., 2016. Report on Lion Conservation with Particular Respect to the Issue of Trophy Hunting. https://www.wildcru.org/wp-content/uploads/2016/12/Report_on_lion_conservation.pdf

Macdonald DW, Daniels MJ, Driscoll C, Kitchener A, Yamaguchi N, 2004. The Scottish Wildcat: Analyses for Conservation and an Action Plan.: Wildlife Conservation Research Unit, University of Oxford. p. 67.

Macdonald, D.W., Loveridge, A.J., Dickman, A., Johnson, P.J., Jacobsen, K.S. and Du Preez, B., 2017. Lions, trophy hunting and beyond: knowledge gaps and why they matter. Mammal Review, 47(4), pp.247-253.

Macdonald, D.W. and Tattersall, F. (2001). Britain's Mammals: The Challenge for Conservation. The Peoples' Trust for Endangered Species, London (ISBN 0-9540043-1-0).

Macdonald, D.W., Yamaguchi, N., Kitchener, A.C., Daniels, M., Kilshaw, K. and Driscoll, D. 2010. The Scottish wildcat: On the way to cryptic extinction through hybridisation: past history, present problem, and future conservation. In: D.W. Macdonald and A.J. Loveridge (eds), Biology and Conservation of Wild Felids, pp. 471-491. Oxford University Press, Oxford.

Macdonald, E. A., et al. 2017. Identifying ambassador species for conservation marketing. Global Ecology and Conservation.(12): 204-214.

Macdonald, E., et al. 2015. Conservation inequality and the charismatic cat: Felis felicis. Global Ecology and Conservation 3: 851-866.

Macdonald, D.W. and Chapron, G., 2017. Outbreeding ideas for conservation success. Oryx, 51(2), pp.206-206.

Maltby M, 1979. The animal bones from Exeter 1971-1975: University of Sheffield, Sheffield.

McGuire, C., and Whitfield, D. 2017. National Water Vole Database and Mapping Project, Part 1: Project report 2006-2015. https://www.wildlifetrusts.org/sites/default/files/201805/water_vole_report_2006-2015_final.pdf

McOrist S, Kitchener AC, 1994. Current threats to the European wildcat, Felis silvestris, in Scotland. Ambio 23:243-245.

Moorhouse T.P., Macdonald, DW, Strachan, R., and Lambin X. 2015. What does conservation research do, when should it stop, and what do we do then? Questions answered with water voles. In DW Macdonald and R Feber (eds) Wildlife Conservation on Farmland, pp 269-290. Oxford University Press, Oxford.

Natural England (2012). Catching and releasing wild game birds: a legal summary. Natural England Technical Information Note TIN 104. Natural England. www.natural England.org.uk. 
Nijman, V. and Shepherd, C.R., 2015. Analysis of a decade of trade of tortoises and freshwater turtles in Bangkok, Thailand. Biodiversity and conservation, 24(2), pp.309-318.

Noddle BA, 1987. Mammalian remains from the Cotswold region. In: Balaam NB, Levitan B, Straker $V$, editors. Studies in palaeontology and environment in south west England: British Archaeological Reports. p. 31-50.

PACEC (2006). The economic and environmental impact of sporting shooting. A report prepared by Public and Corporate Economic Consultants. Available at www.pacec.co.uk.

Pocock RI, 1951. Catalogue of the genus Felis: London: British Museum.

Rackham, O. 1997. The history of the countryside. London, Phoenix Giant.

Reig, S. and Daniels, M.J., 2001. Craniometric differentiation within wild-living cats in Scotland using 3D morphometrics. Journal of Zoology, 253(1), pp.121-132.

Ripple, W. J., et al. (2014). "Status and Ecological Effects of the World's Largest Carnivores." Science 343(6167).

Sage, R.B., Ludolf, C. and Robertson, P.A., 2005. The ground flora of ancient semi-natural woodlands in pheasant release pens in England. Biological Conservation, 122(2), pp.243-252.

Sekhar, A.C., Gurunathan, N. and Anandhan, G., 2004. Star tortoise-A victim of the exotic pet trade. Tigerpaper, 31(1), pp.4-6.

Selier et al 2016. The legal challenges of transboundary wildlife management at the population level: https://www.tandfonline.com/doi/full/10.1080/13880292.2016.1167460

Senn H, Kaden J, Ghazali M, Barclay D, Harrower B, Campbell R D, Macdonald D W, Kitchener AC (submitted). Distinguishing the victim from the threat: SNP-based methods reveal the extent of introgressive hybridisation between wildcats and domestic cats in Scotland and inform future in-situ and ex-situ management options for species restoration.

Senn HV and Ogden R (2015). Wildcat Hybrid Scoring For Conservation Breeding under the Scottish Wildcat Conservation Action Plan (2015), Royal Zoological Society of Scotland, May 2015.

Stahl P, Artois M, 1995. Status and Conservation of the wildcat (Felis silvestris) in Europe and around the Mediterranean rim. Nature and Environment, No 69: Council of Europe. p. 76.

Strachan, R., Moorhouse TP and Gelling M 2011. Water vole conservation handbook ( $\left.{ }^{\text {rd }} \mathrm{Ed}\right)$. Wildlife Conservation Research Unit, Oxford.

Tapper S, 1992. Game Heritage: The Game Conservancy: Fordingbridge. 
Trouwborst, A., Lewis, M.G., Burnham, D., Dickman, A., Hinks, A., Hodgetts, T., Macdonald, E.A. and Macdonald, D.W., 2017. International law and lions (Panthera leo): understanding and improving the contribution of wildlife treaties to the conservation and sustainable use of an iconic carnivore. Nature Conservation 21: 83-128

Virgos E, Travaini A (2005) Relationship between small-game hunting and carnivore diversity in central spain. Biodivers Conserv 14:3475-3486.

Virgós, E., Lozano, J., Cabezas-Díaz, S., Macdonald, D.W., Zalewski, A., Atienza, J.C., Proulx, G., Ripple, W.J., Rosalino, L.M., Santos-Reis, M., Johnson, P.J., Malo, A.F. and Baker, S.E. 2016. A poor international standard for trap selectivity threatens carnivore conservation. Biodiversity and conservation, 25(8), pp.1409-1419.

Vucetich, J.A., Bruskotter, J.T. and Nelson, M.P., 2015. Evaluating whether nature's intrinsic value is an axiom of or anathema to conservation. Conservation Biology, 29(2), pp.321-332.

Vucetich, J.A., Burnham, D., Macdonald, E.A., Bruskotter, J.T., Marchini, S., Zimmermann, A. and Macdonald, D.W., 2018. Just conservation: What is it and should we pursue it? Biological Conservation, 221, pp.23-33.

Williams VL, Loveridge AJ, Newton DJ, Macdonald DW 2015. Traditional medicines: Tiger-bone trade could threaten lions. Nature 523:290-290

Williams VL, Loveridge AJ, Newton DJ, Macdonald DW 2017a. A roaring trade? The legal trade in Panthera leo bones from Africa to East-Southeast Asia PLOS ONE 12:e0185996 doi:10.1371/journal.pone.0185996

Williams VL, Loveridge AJ, Newton DJ, Macdonald DW 2017b. Questionnaire survey of the panAfrican trade in lion body parts PLOS ONE 12:e0187060 doi:10.1371/journal.pone.0187060

Williams VL, Newton DJ, Loveridge AJ, Macdonald DW 2015. Bones of Contention: An Assessment of the South African Trade in African Lion Panthera leo Bones and Other Body Parts. TRAFFIC, Cambridge, UK \& WildCRU, Oxford, UK,

Yamaguchi N, Driscoll CA, Macdonald DW, Kitchener AC, Ward JM, 2004a. Craniological differentiation amongst wild-living cats in Britain and southern Africa: Natural variation or the effects of hybridisation? Animal Conservation 7:339-351.

Yamaguchi, N., Driscoll, C.A., Kitchener, A.C., Ward, J.M. and Macdonald, D.W., 2004b. Craniological differentiation between European wildcats (Felis silvestris silvestris), African wildcats (F. s. lybica) and Asian wildcats (F. s. ornata): implications for their evolution and conservation. Biological Journal of the Linnean Society, 83(1), pp.47-63. 
Yamaguchi, N., Kitchener, A., Driscoll, C. \& Nussberger, B. 2015. Felis silvestris. The IUCN Red List of Threatened Species 2015: e.T60354712A50652361. http://dx.doi.org/10.2305/IUCN.UK.20152.RLTS.T60354712A50652361.en. Downloaded on 01 June 2018.

Ye, Y-C. Yu, W., Newman, C., Buesching, C.D., Xu, Y., Xiao, X., Macdonald, D.W., Zhou Y.B. \& Zhou, ZM. (Subm). On-line consumer-to-consumer sales in exotic pets evade illegal wildlife trade enforcement in China: regional affluence drives demand. Frontiers in Ecology and Evolution.

Zhou Z-M., Johnson R., Newman, C., Buesching, C.D., Macdonald, D.W. \& Zhou Y. 2015c. Tweak Chinese Law to end ivory demand. Nature, 518:303.

Zhou Z-M., Zhou Y., Newman C. \& Macdonald D.W. 2014b. Pangolin: illegal medicine trade threatens these scaly mammals with extinction. The Conversation

Zhou, Z.M., 2014c. China: Synthetic ivory fails to stop illegal trade. Nature, 507(7490), p.40.

Zhou, Z.M., 2015a. China: outdated listing puts species at risk. Nature, 525(7568), p.187.

Zhou, Z.M., Johnson, R.N., Newman, C., Buesching, C.D., Macdonald, D.W. and Zhou, Y., 2015b. Private possession drives illegal wildlife trade in China. Frontiers in Ecology and the Environment, 13(7), pp.353-354.

Zhou, Z.M., Newman, C., Buesching, C.D., Macdonald, D.W. and Zhou, Y., 2016b. Rescued wildlife in China remains at risk. Science, 353(6303), pp.999-999.

Zhou, Z.M., Newman, C., Buesching, C.D., Meng, X., Macdonald, D.W. and Zhou, Y., 2016a. Revised taxonomic binomials jeopardize protective wildlife legislation. Conservation Letters, 9(5), pp.313315.

Zhou, Z.M., Zhou, Y., Newman, C. and Macdonald, D.W., 2014a. Scaling up pangolin protection in China. Frontiers in Ecology and the Environment, 12(2), pp.97-98. 